\title{
Islamic Perspectives on the Genome and the Human Person: Why the Soul Matters
}

\author{
Arzoo Ahmed ${ }^{1}$ and Mehrunisha Suleman ${ }^{2}$
}

\section{Introduction}

A preoccupation with knowledge of the self and nature can be traced throughout human history. From writings of the Ancients to modern scientific inquiries, we find a collocation of ideas that range from the macrocosmic nature of the universe to microcosmic subcellular structures. Recent genomic advances, however, have not only added to a key facet of mankind's raison d'etre-seeking the truth about oneself and the world-it also offers a window into the repercussions of and consequences for manipulating matter on the nature of man, a nature that has hitherto been thought of as being immutable (Savules$\mathrm{cu}$, ter Meulen, and Kahane 2011, XV). The myriad possibilities of genetically manipulating matter for human ends, raises critical questions about such endeavors and how they may influence our understanding of the human person (Savulescu, Ter Meulen, and Kahane 2011, XV). Central to the advances of mankind's ability to understand and manipulate matter is the unlocking of the cellular nucleus and the discovery of DNA with the identification of genes that code for particular phenotypes. This initial discovery has been rapidly applied to subsequent technological breakthroughs in genetic intervention. The latter offers mediation at the sub-cellular level and has the potential to alter the genetic constitution of individuals thereby offering them personalized therapies and unprecedented enhancement. The genetics revolution is thus profound-

1 Arzoo Ahmed is Director at the Centre for Islam and Medicine. She is reading for an MA in Philosophy at King's College London, and has a BA in Physics and an MPhil in Medieval Arabic Thought from the University of Oxford, arzoo.a@gmail.com

2 Dr. Mehrunisha Suleman is a researcher at the Centre of Islamic Studies, University of Cambridge. She has completed a DPhil in Population Health and a Medical Degree at the University of Oxford, ms52o@cam.ac.uk

(C) ARZOO AHMED AND MEHRUNISHA SULEMAN, 2019 | DOI:10.1163/9789004392137_007

This is an open access chapter distributed under the terms of the prevailing CC-BY-NC License at the time of publication. 
ly influencing our understanding of the human person, inheritance, genetic and species relatedness and distinctiveness. Concurrently, such advances have raised urgent moral questions about our ability to alter and influence the genetic makeup of individuals, and the potential adverse ethical impact these may have on future generations.

Recent genetic innovations have been studied through the prism of variegated fields including philosophy, theology and ethics. But very few studies have focused on the Islamic tradition's perspectives on the human genome and the human person. A constellation of Islamic philosophical, theological and spiritual narratives have contributed to the definitions for and understanding of the human person. Central to such accounts is the nature and role of the soul in defining and determining the human person. Yet very few scholarly contributions consider the relationship between the human genome, its association with the human person, and how these relate to Islamic considerations of the soul. The aim of this paper is to redress this imbalance.

This study seeks to extend the list of textual sources that contribute to ethical considerations of the genome question. We will show that these issues must, of necessity, include discussions of the human person and interrogate the interplay between them. Based on this hypothesis, this work will argue that, within the Islamic tradition, deliberations on the genome question should take into account knowledge of the soul and the body, since these are also believed to be constituents of the human person. Observations on these two primary determinants of the human person will be proffered from the fields of Quraanic exegesis, theology, and philosophy. The modus operandi of this investigation will be the exploration of key terms, how they relate to the approaches of different fields, and how they are conducive to offering a deeper understanding of the human person. The study will initially propound the relationship between the genome and the human person and how perspectives on the human genome are informing ideas about the human person and how such positions are stimulating ethical deliberations around speciesism, genetic determinism, enhancement, capacities, will and responsibility. This will be followed by an explication of the soul from within the Islamic tradition and how narratives from within this tradition provide novel perspectives to our understandings of the human person and the ethical considerations surrounding genomics. Finally, we will delineate areas for future engagement that this study has disinterred. 


\section{On the Relationship between the Genome and the Human Person: Definitions, Perspectives and Challenges}

Genetic advancement, through the elucidation of the structure of DNA (Watson and Crick 1953) and the subsequent sequencing of the Human Genome,, has propelled us to a higher plateau of understanding our basic functions and the nature of human life (IHGSC 2004; Lander et al. 2001). Such developments are changing, not only what we can do, but also how we think and understand ourselves (Annas 1997, 157). George Annas explores how the mapping of the human genome has been a powerful "thought transformer" (Annas 1997, 157) similar to that of the astronomical mapping by Copernicus and the global mapping by Columbus. He argues that "maps model reality to help us understand it" (Annas 1997, 157). This proposition requires careful consideration visà-vis the mapping of the human genome in deriving understandings of the human person. The conceptualization of the human person from scientific, philosophical, ethical and legal perspectives, often refer to a composite - a person with distinct yet interacting parts (Taylor 1985). These fields oblige us to re-evaluate our understanding of the human person in light of genomics. This section will briefly explore perspectives on the human genome that are informing ideas about the human person and how such positions are stimulating ethical deliberations around speciesism, genetic determinism, enhancement, capacities, will and responsibility.

\section{The Role of Genes in Determining Our Species Identity: Who Are We?}

"Who are we? The question must be answered by each generation," suggests Archbishop Desmond Tutu reflecting on our need to reconcile recent scientific advancements with long held beliefs (Tutu 2015, ix). The discovery that our genes may define us as a species, Homo sapiens, brings into focus how pivotal scientific discoveries often involve "narcissistic offences" (Zwart 2009). Hub Zwart explains, for example, that scientific developments realized through Copernican heliocentrism demonstrate that earth and man do not occupy a central position in the organization of the universe; rather, we are deemed to be equals amongst other bodies in space (Zwart 2009). He adds that Darwin's seminal work on evolution elucidated how little we differ from other species (Zwart 2009), and that these estimations have been proven through comparative genomics, which reveal that humans may share up to $99.4 \%$ of their DNA with chimpanzees (Wildman et al. 2003). 
Ethical considerations resulting from such findings are being realized through recent deliberations about and investigations into the moral status of Homo sapiens. Those who define being human along genetic lines argue that our species distinction confers certain privileges. This speciesism involves claims that humans should be able to manipulate other species for their own ends, such as killing them for food or using them for research (Steinbock 1978). The argument for employing the concept of a "genetic humanity" (Warren 2013,308 ) as a way of defining human beings, is advocated by those who argue against abortion suggesting that it is wrong, not simply because fetuses are alive, but because they are human. However, this definition would require further evaluation when attempting to tackle questions around the best interests of the mother and fetus. If both are equal, since both are human, that is, each carries the human genome, then life-saving prioritization decisions cannot be made between mother and fetus on this basis.

Others, however, emphasize that comparative genomics, rather than conferring upon humans a genetic distinctiveness, demonstrate that, as a species, we are merely one entity on the species spectrum (Zwart 2009). How then do we relate to one another and comprehend, not only our identity as human beings, but also our identity as distinct persons? Peter Singer, who advocates for animal liberation, does, nevertheless, concede that human animals are distinct from non-human animals (Singer 1975; Steinbock 1978). If our genetic code alone does not confer such distinctness, then what accounts for it? And how can we understand intra-species differences, such as that of a mother and her fetus? Genomics may offer avenues for answering these questions, not through the Human Genome's application as a species map, but through it's conferring of individual phenotypic traits and therefore physical realities and capacities.

\section{The Role of Genes in Determining Our Individual Identity: Who Am I?}

James Watson, who co-discovered DNA with Francis Crick, famously claimed, "We used to think our fate was in our stars. Now we know, in large measure, our fate is in our genes" (Watson 1989). Richard Dawkins, in his pioneering work on evolution posits: "They (genes) are in you and in me; they created us, body and mind; and their preservation is the ultimate rationale for our existence. They have come a long way, those replicators. Now they go by the name of genes, and we are their survival machines" (Dawkins 2016). Such claims rely on reductionist models of the human person, which suggest a linear causal link between genes, the proteins for which they code, the subsequent cellular pro- 
cesses they initiate, their amalgamation at the level of individual tissues and organs and, finally, organ systems that are eventually realized as an entire human organism (Noble 2008). These models of biological systems find support in examples of so-called "genetic determinism" (Peters 2014) where genes determine phenotypic outcomes, illustrated by conditions such as Huntingdon's disease (HD) and cystic fibrosis (CF).

$\mathrm{CF}$ is a genetic disorder characterized by an autosomal recessive pattern of inheritance (Rommens et al. 1989). The disease is caused when an individual inherits mutations in both copies of the gene that code for the cystic fibrosis transmembrane conductance regulator (CFTR) protein. The condition affects multi-organ systems including the respiratory tract, reducing lung capacity, and impairing digestion resulting from suboptimal functioning of the pancreas; inheritance of the recessive alleles predict the presence of disease at birth. Currently, no treatment exists for CF and management comprises symptomatic relief for individual organ systems. It is a life-limiting disease (Tobias, Connor and Ferguson-Smith 2011) wherein the identification of the CF gene (Rommens et al. 1989) has raised the possibility of genetic intervention. Gene therapy targeting the faulty CFTR gene in individuals who carry the mutation has been hailed as a potential biomedical magic bullet for suffers of $\mathrm{CF}$ (Colledge and Evans 1995).

The identification of genes and their resulting phenotype, as well as the concurrent development of techniques to modify these genes hold great diagnostic and therapeutic potential. Nor are their uses limited to single gene disorders such as CF. Genetically predisposing factors such as the presence of BRCA1 and 2 in breast and ovarian cancer present subcellular level targets that may alter or ameliorate the risk of disease. The ability to alter our genetic makeup and in turn reduce risk of disease holds immense potential benefit. These advances and their proposed potential have also been welcomed as evidence for theories of genetic determinism. It also leads to claims that such genetic intervention ought to be pivotal in shifting our understanding of the fate of humans. For individuals carrying the genes that code for a potentially debilitating condition, like CF, gene therapy would undoubtedly have a tremendous impact on their sense of self and quality of life. It would thus support the notion that genetic intervention through gene therapy plays a critical role for genes in determining the human person by offering an unprecedented ability to alter the fate of humans at the level of the germ line.

Such genetic interventions also raise ethical concerns, however, around the human person in terms of health, illness and quality of life. Few would argue that to intervene at the genetic level to prevent or treat a debilitating condition, like CF is ethical. But what can be said of gene therapy induced cosmetic 
changes or the potential to extend life through telomere repair? How do we distinguish between therapeutic benefit and enhancement when both aim to improve quality of life? A genotypic emphasis for understanding normal traits (Buchanan et al. 2001) and the human person raise questions, not only about our existing attributes, but also about our aspirational endeavours. Who do we want to become? Some authors argue that it is not only desirable but also a moral obligation to enhance ourselves (Savulescu, ter Meulen, and Kahane 2011). If such enhancement enables people to lead better lives, the argument goes, then we have a responsibility to promote such an endeavor. Human engineering or "transhumanism" raises hopes in many spheres about how the human species can be advanced in fields of physical and intellectual endeavor.

Nevertheless, such views raise critical questions about what it means to lead a good life or better life. These discussions highlight the need for societies to gain a deeper understand of the meaning of health, disease and wellbeing in the wake of genetic intervention and enhancement. Modern eugenics or selective breeding to "optimize" the population gene pool is commonly practiced, with genetic testing and subsequent selection against disorders such as Down's syndrome. This practice is considered acceptable as it is predicated on parental consent and has the overall objective of producing a child with the best opportunities for a good life (Savulescu 2009). However, are people the best guardians of their own interests and capable of making appropriate choices, not just for themselves, but also for their offspring and future generations? The potential uses of genetic technologies have revolutionized our understanding of biomedical therapeutics and enhancement. However, such innovations have raised not only bioethical questions about personal capabilities, but also potential diachronic implications for future generations.

When biomedical interventions seek to be both lifesaving and life enhancing, how do we decide the boundary between enhancement and therapy? Consideration of genetics alone does not enable us to answer such questions. Instead, they require a deeper evaluation of how we individually, and collectively, understand concepts such as quality of life and suffering, and alleviation thereof. It is also important to consider that few diseases confer such a strong causal link, such as is seen in CF, between genotype and phenotype. The human phenotype comprises, not just physical characteristics such as eye color or a faulty protein, it also constitutes features such as behavior and general disposition. How far do genes account for these other aspects of our phenotype? Studies of twins reveal that they can share identical genotypes, yet display distinct phenotypes. Individual genotypic definitions of the human person are therefore limited and require us to consider broader phenotypic models that incorporate features such as our behavior and general disposition. 


\section{The Role of Genes in Determining Human Psychology: Am I My Thoughts and Actions?}

Crick believes the role of genes determine thoughts and actions. He remarks, "You, your joys and your sorrows, your memories and your ambitions, your sense of personal identity and free will, are in fact no more than the behavior of a vast assembly of nerve cells and their associated molecules" (Crick 1994, 3). Other scientists, on the other hand, caution against such genetic determinism by emphasizing that "stretches of DNA that we now call genes do nothing on their own. They are simply databases used by the organism as a whole" (Noble 2008, 18). Denis Noble goes on to argue that genes are "captured entities, no longer having a life of their own, independent of the organism" (Noble 2008, 18). Dawkins also recently clarified that in his thesis, "The Selfish Gene," the "anthropomorphic personification" (Dawkins 2016, xi) of DNA that was initially employed ought to be clarified. He explains that "no sane person thinks DNA molecules have conscious personalities" (Dawkins 2016, xii) and that the personification of molecular structures simply offers scientists a "didactic device" (Dawkins 2016, xii). The disambiguation of Dawkins notwithstanding, there have been increasing misconceptions about the role of genes in determining behaviors and psychologies. Studies show growing cognitive biases in terms of genetic essentialism where people consider that their lives, thoughts and behaviors are an inevitable reflection of their genotype (Dar-Nimrod and Heine 2011).

The discussion hitherto has been on the role of genes in determining the human person with regards to our species identity as Homo sapiens, and to their lesser role in determining our individual biological composition through physical phenotypic determination. As persons, however, our identity goes beyond belonging to a species and having a physical or bodily identity. Some authors have suggested that "persons are separate entities to human beings" (Savulescu 2009, 220). Charles Taylor, in his ground-breaking account of "Human Agency and Language," elucidates the concept of a person. He writes:

Where it is more than simply a synonym for 'human being, 'person' figures primarily in moral and legal discourse. A person is a being with $a$ certain moralstatus, or a bearer of rights. But underlying the moral status, as its condition, are certain capacities. A person is a being who has a sense of self, has a notion of the future and the past, can hold values, make choices; in short, can adopt life-plans. At least, a person must be the kind of being who is in principle capable of all this, however damaged these capacities may be in practice. (Taylor 1985, 97) 
Moral philosophers, such as Singer, argue that what characterizes us as persons and confers upon us certain moral implications, is not membership within the species: Homo Sapien, but rather, the particular properties of rationality and self-consciousness (Singer 2011, 83-87). Both of these accounts indicate that a person is someone who is able to retain a sense of self over time and hold values and preferences into the future. Additionally, Julian Savulescu comments that a necessary, but not sufficient, component of persons is their "capacity to act from normative reasons, including moral reasons" (Savulescu 2009, 243). $\mathrm{He}$ also explains that "animals have desires and wants about what to do. $\mathrm{Hu}$ mans alone have beliefs about what they should do" and that they "sometimes act on the basis of these" (Savulescu 2009, 244).

Such philosophical narratives imply a complex interplay between genetic predispositions, rationality and how we relate to our past and future selves. Yet there are also claims that particular genetic traits predispose to certain actions that challenge notions of individual reasoning and will, and subsequent notions of responsibility. For instance, the XYY or super-male karyotype, which has been linked with criminal behavior (Farrell 1969), has been employed as a legal defense. Individuals arrested for a crime who were found to have this genetic makeup argued that, due to a genetic predisposition, they could not be held responsible and should thus not be considered criminally accountable for their actions. This so-called "XYY defence" has broadly been rejected and, in cases where it was accepted, it was on the grounds of diminished mental capacity, where the defendant was confined to a mental institution (Annas 1997, 158). Be that as it may, the "XYY defence," and genetic myths (Fox 1971) implying genes are the "metaphorical locus of our fate" (Wolpe 1997), bespeak not only a nascent understanding of how and if genes impact our ability to reason and act, they exhibit our willingness to believe that such faculties are beyond our conscious control (Dar-Nimrod and Heine 2011). Sigmund Freud, for example, famously posited that we are not rationally driven beings and are entirely subject to our subconscious (Zwart 2009). Freud's psychoanalysis thesis forces a further reconfiguration of our understanding of the human person and the role of the human genome in the latter's determination. Current and future developments within science, psychology, philosophy and ethics will continue to inform such discussions.

It is important to reflect here that recent research has also elucidated the role of genes in determining non-physical characteristics. Studies have illustrated the genetic heritability of a range of cognitive abilities, including intelligence (Plomin and Spinath 2004). However, these links are posited currently as possibilities and not accurate predictions. Such advances also raise ethical concerns about future possibilities of artificially selecting for such genes. The 
ethical implications of "designer descendants" are vast; including how such interventions may alter our capacity for moral reasoning. If these designer descendants are genetically selected and programmed to be morally infallible, then are such entities still considered persons? Such interventions would have an unprecedented bearing on our understandings of free will, consciousness, determinism, responsibility and our aspirations for and obligations towards future generations of "persons."

The foregoing displays how genetic advancements, which have offered new perspectives on our understanding of the human person, have also stimulated novel ethical deliberations. Accounts presented above indicate that there are many gaps in our construction of the human person when relying solely on the genome. Ethical deliberations around speciesism, genetic determinism, enhancement, capacities, will and responsibility that are stimulated by the human genome also require broader examination through additional sources of knowledge. The scientific, ethical, philosophical and legal accounts of the human person presented above suggest that more work needs to be done to characterize the human person, in terms of personal and collective traits, before the associated ethical considerations can be fully addressed and scrutinized. Now we offer perspectives from the Islamic tradition and, in particular, accounts on the human soul, which offer novel perspectives on aspects of the human person, and the associated ethical considerations surrounding the genome question.

\section{On the Relationship between the Soul and the Human Person within the Islamic Tradition: Definitions, Perspectives and Implications for the Genome Question}

Knowledge about the concept of the human person is informed, not only through biological and scientific advances as they relate to the genome, and other fields of inquiry mentioned earlier, but also through religious and spiritual traditions which offer specific insights into the non-physical dimensions of the human person.

The concept of the human person within the Islamic tradition commonly features in bioethical discussions concerning abortion and the specific events marking the beginning and end of life (Brockopp 2008; Ghaly 2012; Shaw 2014). In these contexts, the human person is defined in accordance with the status conferred upon it by the movement of the soul as it enters or leaves the human body. A broader consideration of what constitutes the human person, and the nature of the soul, according to the Islamic tradition, is not only helpful, but 
also necessary before assessing the impact and implications for the genomics project.

Key Qurānic terms that relate to the physical and spiritual aspects of the human person are identified and explored within various disciplines of Islamic thought. Here we will present a narrative on the human person that combines beliefs about the body, soul and spirit - their origins, existence, fate, and purpose of creation. The primary focus is on highlighting the complexity that the existence of a soul adds to a conceptualisation of the human person. Where possible, the implications for the genomics project are touched upon, insofar as they may impact the soul's propensity for reflecting on and returning to its pure and natural (fitrah) primordial state, as originated by God.

\section{Defining Key Terms Related to the Human Person: Qurānic, Theological and Philosophical Perspectives}

This section surveys Qurānic terms related to the human person, which are further elaborated in exegetical, theological and philosophical sources. Table 1 displays these terms, their associated translations and their frequency of occurrence in the Qur'ān. 
TABLE 1 Key terms from the qur'ān relating to the human person

Arabic term Translation Frequency Note

$\begin{array}{ll}\text { in Qửān } & \text { of term in } \\ \text { Qurān }\end{array}$

References of Qur'ānic verses mentioning term

\begin{tabular}{|c|c|c|c|c|}
\hline Insān & $\begin{array}{l}\text { Man, } \\
\text { mankind, } \\
\text { human } \\
\text { beings }\end{array}$ & $71^{*}$ & & $\begin{array}{l}(2: 60)(4: 28)(7: 82)(10: 12) \\
(11: 9)(12: 5)(14: 34)(15: 26) \\
(16: 4)(19: 67)(21: 37)(22: 66) \\
(23: 12)(82: 6)(89: 23)(96: 5) \\
(100: 6)\end{array}$ \\
\hline Ins & $\begin{array}{l}\text { Men, } \\
\text { mankind }\end{array}$ & 18 & & $\begin{array}{l}(6: 112)(6: 128)(6: 130)(7: 38) \\
(7: 179)(17: 88)(27: 17)(41: 25) \\
(41: 29)(46: 18)(51: 56)(55: 33) \\
(55: 39)(55: 56)(55: 74)(72: 5) \\
(72: 6)\end{array}$ \\
\hline Bashar & $\begin{array}{l}\text { Man, } \\
\text { human, } \\
\text { human } \\
\text { beings }\end{array}$ & $37^{*}$ & & $\begin{array}{l}(3: 47)(3: 79)(5: 18)(6: 91) \\
(11: 27)(12: 31)(14: 10)(14: 11) \\
(15: 28)(15: 33)(16: 103) \\
(17: 93)\end{array}$ \\
\hline Arḍ & Earth & 2 & $\begin{array}{l}\text { Arḍ occurs } 461 \text { times, but } \\
\text { only on two occasions does it } \\
\text { refer to the human being as } \\
\text { produced from earth (arḍ)** }\end{array}$ & $(11: 61)(53: 32)$ \\
\hline Ṭin & Clay & 8 & $\begin{array}{l}\text { Material out of which the } \\
\text { human being was fashioned }\end{array}$ & $\begin{array}{l}(6: 2)(7: 12)(17: 61)(23: 12) \\
(32: 7)(37: 11)(38: 71)(38: 76)\end{array}$ \\
\hline Turāb & Dust & 14 & $\begin{array}{l}\text { Half of the verses refer to the } \\
\text { human being's creation from } \\
\text { dust, other half refer to the } \\
\text { human being's return to dust }\end{array}$ & $\begin{array}{l}(3: 59)(13: 5)(18: 37)(22: 5) \\
(30: 20)(35: 11)(40: 67)(23: 35) \\
(23: 82)(27: 67)(37: 16)(37: 53) \\
(50: 3)(56: 47)\end{array}$ \\
\hline șalșāl & Clay & 4 & $\begin{array}{l}\text { Three of the references } \\
\text { describe the clay as being from } \\
\text { an altered black mud }\end{array}$ & $(15: 26)(15: 28)(15: 33)(55: 14)$ \\
\hline Jasad & Body & 1 & Refers to the prophets' forms & $(21: 8)$ \\
\hline Badan & Body & 1 & $\begin{array}{l}\text { A purely physical bodily form } \\
\text { after the spirit has departed }\end{array}$ & $(10: 92)$ \\
\hline
\end{tabular}


TABLE 1 Key terms from the qur'ann relating to the human person (cont.)

Arabic term Translation Frequency Note

in Qurān of term in

Qurān
References of Qurānic verses mentioning term

\begin{tabular}{|c|c|c|c|c|}
\hline Qalb & Heart & $132^{*}$ & & $\begin{array}{l}(2: 7)(2: 10)(2: 74)(2: 88)(2: 93) \\
(2: 204)(2: 283)(3: 7)(3: 126) \\
(3: 156)(4: 155)(5: 41)(6: 25) \\
(7: 100)(7: 179)(9: 93)(9: 127) \\
(10: 88)(26: 89)(33: 26)(41: 5) \\
(49: 7)(50: 33)(57: 16)(61: 5) \\
(66: 4)(74: 31)\end{array}$ \\
\hline Fu’ād & Heart & 16 & & $\begin{array}{l}(6: 110)(6: 113)(11: 120) \\
(14: 37)(14: 43)(16: 78)(17: 36) \\
(23: 78)(25: 32)(28: 10)(32: 9) \\
(46: 26)(53: 11)(67: 23)(104: 7)\end{array}$ \\
\hline șūra & Form & 3 & $\begin{array}{l}\text { The perfected form of human } \\
\text { beings }\end{array}$ & $(40: 64)(64: 3)(82: 8)$ \\
\hline Taqwīm & Mould & 1 & $\begin{array}{l}\text { The stature or mould of human } \\
\text { beings }\end{array}$ & $(95: 4)$ \\
\hline Nafs & Soul & 290 & $\begin{array}{l}\text { In an additional } 5 \text { verses, God } \\
\text { refers to 'Himself' using the } \\
\text { same root word nafs. Occurs } \\
\text { as a noun denoting 'soul,' 'self,' } \\
\text { 'person,' 'mind,' dependent } \\
\text { upon context }\end{array}$ & $\begin{array}{l}(2: 9)(2: 44)(2: 48)(2: 54)(2: 72) \\
(2: 123)(2: 155)(3: 93)(5: 32) \\
(5: 70)(5: 80)(5: 116)\left(6: 15^{2}\right) \\
(7: 42)(7: 189)(9: 81)(9: 118) \\
(11: 21)(12: 53)(13: 42)(17: 15) \\
(21: 35)(39: 6)(41: 31)(50: 21) \\
(82: 19)(91: 7)\end{array}$ \\
\hline Rūḥ & Spirit & 21 & $\begin{array}{l}\text { References the spirit of God, } \\
\text { the Holy spirit, the spirit in } \\
\text { human beings, inspiration, as } \\
\text { well as the angel Gabriel }\end{array}$ & $\begin{array}{l}(2: 87)(2: 253)(4: 171)(5: 110) \\
(15: 29)(16: 2)(16: 10)(17: 85) \\
(19: 17)(21: 91)(26: 193)(32: 9) \\
(38: 72)(40: 15)(42: 52)(58: 22) \\
(66: 12)(70: 4)(78: 38)(97: 4)\end{array}$ \\
\hline ‘Aql & $\begin{array}{l}\text { Intellect, } \\
\text { reason }\end{array}$ & $49^{*}$ & $\begin{array}{l}\text { Not mentioned as a noun. } \\
\text { Occurs as form I verb 'aqalu } \\
\text { meaning to understand, } \\
\text { reason, intellect }\end{array}$ & $\begin{array}{l}(2: 44)(2: 73)(2: 76)(2: 164) \\
(3: 65)(3: 118)(5: 58)(5: 103) \\
(10: 16)(12: 2)(29: 43)(30: 24) \\
(36: 68)\end{array}$ \\
\hline Fițrah & Nature & 1 & $\begin{array}{l}\text { Original, natural state upon } \\
\text { which God created human } \\
\text { beings }\end{array}$ & $(30: 30)$ \\
\hline
\end{tabular}


* Terms with a large frequency where only select references are mentioned.

** Nine Qurānic verses mention God making humans 'vicegerents' (khaliffah) on earth (arḍ). Four of those mentions (Q. 2:30;6:165; 27:62;35:39) refer to vicegerents on earth in the general sense. It appears that being a vicegerent on earth is a property of humans that is intrinsically tied to their physical existence on earth. Humans, produced from earth, sent through the Fall to be vicegerents on earth, must inevitably return to earth through death, and be resurrected again from earth, before continuing their journey to the hereafter.

The term $n \bar{a} s$ (translated as people, or mankind) occurs 241 times as a noun in its plural form. This has been omitted from the table because it is employed as a general address to humans, which is extraneous to the specific physical and spiritual constitution of the human person that this paper addresses.

In the Qurānic narrative, man (insān/bashar) was created from clay (țīn/ șals ăl) and dust (turāb) (Q. 32:7; 15:28; 35:11), and fashioned (șawwara) into the best of forms (șuwar) (Q. 64:3), before God blew into him, of His spirit (rüh) (Q. 38:72). Elsewhere in the Qur'ān, God states that "He created you from a single soul (nafs)" (Q. 4:1). Man is thus constituted of three key elements: the form (encompassing the body), the soul, and the spirit, and has been endowed with a physical and spiritual existence, both of which are central to a conception of the human person.

Yet, as Table 1. clearly demonstrates, these terms are not equally significant in the Quraanic narrative. Of all the terms outlined, one stands out as being the most important: nafs. This term features in the Qur'an more than fourteen times its potential synonym, rūh. It is used more than twice as many times as its nearest related term $(q a l b, 132)$, and it is cited with a significantly higher frequency as compared to all the other terms under consideration combined (290: 379). There can be little doubt, then, as to its centrality from a Qur'ānic perspective. Any study that makes bold to address the notion of the human person in the Islamic tradition, therefore, must place nafs at the centre of that endeavour. This is the reason nafs shall assume pride of place in this paper, with all other terms being examined as they are connected to or affiliated with it.

\section{Nafs and rūh: Distinct Entities or Synonyms?}

A person's metaphysical and spiritual existence is predicated on, and determined by, the existence of nafs (soul, self) and rüh (spirit). From Table 1, it can be seen that the Qurān mentions nafs far more frequently than rūh (290:21, respectively). The vast array of verses that mention nafs provide copious in- 
formation about its nature, its different levels and functions, and how it sometimes inclines towards good and, at other times, away from it. On the other hand, the Qur'ān is far less expansive in its elucidation of rüh: "They question you about the Spirit (rühn). Say: the Spirit is from the command of my Lord. And you have not been given knowledge about it, save a little." This verse bespeaks an essential numinosity, which is why many scholars chose not to elaborate on matters pertaining to the spirit.

The renowned exegete, Abū 'Abd Allah al-Qurțubī (d. 671/1273), writes "it [the rūh $\underline{\text { ] }}$ is a great matter and a significant affair from the matters of God that He has obscured for us and not explained, so that man realizes his apodictic incapacity to know the reality of his self, whilst knowing that [his reality] exists. And if man is so incapable of knowing his own reality, then he is, a fortiori, incapable of knowing the reality of God" (Qurțubī 2004, 10: 210).

Some scholars hold that nafs and rūh are one and the same, thus the terms for each can be used interchangeably to indicate the masculine and feminine forms of the soul. Others, like Saìd Hawwa, distinguish superficially between the two entities, and posit that rüh is the form of the spirit's independent existence prior to being affiliated with a body, and that rūh resides as nafs after it is "clothed in the body" (Sa'id Hawwa 1995). Thus, nafs is a term for the body being fertilized with the spirit.

Not all orthodox scholars accepted the synonymy of nafs and rüh; the Sufi exegete, 'Abd al-Karīm al-Qushayrī (d. 465/1072), for instance, comments that, "rūh is the locus of subtle states (ahwāl latîfah) and praiseworthy actions, just as sight is the locus of visions... the rüh is [thus] the locus of all praiseworthy attributes, just as nafs is the locus of all blameworthy ones" (Qushayrī, 4: 304).

The Qurān assigns three states to nafs: the satisfied soul (nafs al-mutma-innah) (Q. 89:27); the self-accusing soul (nafs al-lawwämah) (Q. 75:2); and the soul inclined to evil (nafs al-ammärah bi'l-sü') (Q. 12:53). That nafs is associated with states inclined towards actions, both good and bad, means that it offers a tangible link between the physical and metaphysical dimensions of a person.

Others were more succinct, and offered a deeper distinction between $n a f s$ and $r \bar{u} h$, stating that "the latter is that whereby is life; and the former, that whereby is intellect ('aql), or reason; so that when one sleeps, God takes away the nafs, but not the rüh, which is not taken save at death" (Lane, Arabic Lexicon, 1111). Opinions of scholars citing a significant difference between $n a f s$ and rūh present a perspective that is more coherent with the Qur'annic characterization of both aspects of the human person. In the Qurān, God attributes rūh to Himself, as part of His command, whereas nafs is more directly associated with humans. Were nafs and rüh similar in their origin, existence and function, the Qurān would not have distinguished between the two so clearly, by 
specifying that $r u \bar{h} h$ is from the matter of God, of which we know little, whilst offering far greater insight into nafs.

A consideration of nafs, therefore, is more conducive to constructing a framework connecting the physical and metaphysical aspects of the human person, particularly through the lens of human action. That there is an intimate connection between the body (jasad, jism, badan) and the nafs, it is impossible to deny. But how are they connected, and how, and to what extent, do actions of the body influence the soul?

\section{Nafs and Body}

The body and soul are intimately connected. The mystic Muhammad b. al-Husayn al-Sulamì (d. 412/1021), writes that 'the soul is a band of rays of the Reality whose traces differ in bodies' (al-Sulamì 2001, 1:395). The soul is the receptor of the Divine ray, whose output is through the body. The soul thus percolates through the actions of the body, and so, would it be too outlandish to assert that the actions of the body, in mutualistic fashion, affect the soul? Before we consider this specific conundrum, we must look at the general relationship between the body and the soul, and whether the human person is the body alone, or the body-soul amalgam.

The Qur'ān asserts that 'every soul (nafs) shall taste death' (Q. 3:185). The term employed in this verse, $n a f s$, is significant because there is unified opinion that the soul (nafs) does not die. It is the body that dies, its death marked by the departure of the soul. Thus, in this verse, the term nafs more literally represents the body or person, who experiences death. It is indeed the case that the Qurānic usage of the term nafs oscillates between 'soul' and 'self' and the 'human person' emphasizing the inextricable association of the body and soul. The Qur'an's deliberate application of the term nafs to indicate both physical and metaphysical realities supports the body-soul amalgam of the human person, addressing what is visible: the body, and that which isn't visible: the soul.

The nature of the interaction between the body and the soul was of central concern to Muslim philosophers and theologians. Their debates about the nature of the human person took place within wider discussions about human agency and theories of action, as they sought to understand nature, their role as humans, and the role of God (Wolfson 1976; Calverley and Pollock 2002). Their discussions and the questions they raised resonate within our current scientific milieu, as we tread the boundaries of what is natural and question again what it means to be a human person. 
Many opinions circulated among theologians, as al-Ash arī (d. 324/935) in his doxographical work, Maqualāt al-Islämiyyīn, catalogues. The discussions ranged from whether the body alone could define man, that is, "the individual that you see," or whether accidents ( $\left.a^{c} r \bar{a} d\right)$, too, formed part of the body. A group opined that the body itself is man and its accidents are not part of it. It was also debated whether the soul was regarded as a separate substance (jawhar) to man, in addition to the body. Dirār b. 'Amr (d. 20o/815?), rejecting the idea of a spirit or an immaterial soul, remarked "man is made up of many things, namely: colour, taste, smell, the ability to touch and so forth. They constitute man whenever they are combined and there is no separate substance other than these." Others, like the dualist Bishr b. al-Mu'tamir (d. 210/825), disagreed, "man is body and spirit, and these two together constitute man" (Ritter 1929, 329). Writing a couple of centuries later, Al-Rāghib al-Ișfahānī (d. 502/1108) conveyed his understanding of the role of the body and soul, respectively: "man (insān) is composed of a body (jism) with the faculty of sight (bașar), and a soul (nafs) with the faculty of insight (bașira)'... the soul is the locus of spiritual accidents, and the body the locus of bodily accidents" (Mohamed 2006, 456).

In his capacity as a celebrated physician, Avicenna (d. 429/1037) wrote about the human body, most notably in his Canon of Medicine, whilst as a distinguished philosopher, he wrote on the human soul, and how intellectual perfection allows the soul to attain ultimate happiness. Avicenna, adopting the Aristotelian concept of the soul, defines it in his magnum opus, al-Najät as "the first entelechy (perfection) of a natural body possessing organs that potentially has life" (Rahman 1952, 25). The soul, therefore, is the defining feature that perfects a body to make it part of a species and distinct from other species. Avicenna's conception of soul as "entelechy is wider than that of form" because forms necessarily subsist in matter, whereas entelechy allows the soul to be associated with the body without exclusively being a form inherent in the body (Rahman 1952, 9).

Avicenna postulates a tripartite division of the souls (vegetative, animal, and human). These are bifurcated into the physical (vegetative and animal) and spiritual (human) souls, with the former "passing away upon the death of the body" and the latter (human, spiritual) being classified as an "independent and immaterial substance" (Rahman 1952).

Although the foundations of an immaterial soul were laid by the Ancient Greeks, with Plotinus asserting that the 'soul is not in the body as in space, it is not related to the body as form to matter, as a whole to a part or a part to a whole,' it was Avicenna, who, through his unique thought experiment of 'the flying man,' helped explain the immaterial nature of the soul as a form of con- 
sciousness and self-awareness. He thus opined that the soul, by its very nature, has self-knowledge (Reisman 2004).

The immortality of the soul is another unique aspect of Avicenna's definition of the soul. In chapter 13 of his Najāt, the philosopher writes, "we say that the soul does not die with the death of the body and is absolutely incorruptible. As for the former proposition, this is because everything, which is corrupted of something else, is in some way attached to it. And anything, which is in some way attached to something else, is either coexistent with it or posterior to it in existence or prior to it, this priority being essential and not temporal (Rahman 1952, 58).

Avicenna's theory of the substantiality of the soul and the assertion of the separability of the human rational soul from the body grants the soul an independence from the body. Goodman comments on the idea that the soul does not exist in the body as mere form in a substrate. He states that "human actions are not to be conceived solely in terms of the behavior of the body, and are not reducible to physical terms or explicable wholly and solely by reference to mechanical events... souls can affect bodies; it is not always a case of bodies affecting souls... this thesis is crucial to our ability to maintain or restore the idea that a person is an agent, that human thought, action and experience are not adequately described or explained in mechanistic terms" (Goodman 1992, 161).

The soul's experience of life on earth is intrinsically tied to the body. al-Attas writes that "the human body and the world of sense and sensible experiences provide the soul with a school for its training to know God" (al-Attas 1995, 175). Further questions can also be posed about whether the body and soul are independent in the spiritual sense, since physical actions have been shown in the Qur'ān and other writings, to have an effect on the human person's spiritual existence, and eternal fate. To disinter the full complexity of this relationship, we must first look at the point when the body and soul became united.

\section{How Old is the Association between the Body and the Soul? The First Covenant}

The story of creation, which details different stages and events in the origin of the human person and its purpose for creation, is useful in providing further insights into the nature of the soul and how it relates to physical, psychological and spiritual aspects of the human person, in the space-time realm which precedes that of the human being's earthly existence. In its primordial existence, as described in the Qurān, the human being took his first covenant: "And (re- 
member) when your Lord brought forth from the Children of Ādam, from their loins, their seed, and made them testify about themselves, (saying): Am I not your Lord? They said: Yes, verily. We testify" (Q. 7:172).

Scholars, who have commented on this first covenant and the nature of the extraction of human beings from the loins of Âdam, differ concerning the form of human existence during the event. Some assert that the covenant was taken in a corporeal form, whereas others hold that it was just the souls that were gathered for this moment and testified. Ibn Jarī al-Tabarī (d. 310/923) cites 'Abd Allāh ibn 'Abbās (d. 74/687), the exegete par excellence, as having said, 'When God created Ādam, He extracted his progeny from his back [and they were] like atoms (dharr).' Al-Tabarī is more categorical as to the constitution of Ādam's progeny, when he states that upon extraction from Ādam, his progeny was 'in the form (hay'a) of atoms (dharr)' (al-Tabarī 2005, 6:111). The lesser-known exegete, Abū Isḥāq al-Tha ālibī (d. 427/1035), avers that the souls were either like atoms (dharr) or mustard seeds (khardal). He then quotes $\mathrm{Mu}$ hammad ibn Ka'b (d. 108-120/726-738?) who remarks, "they were souls (arwāh) to whom a task was given' (al-Tha ālibī 1996, 1:586). Al-Qurțubī also records the viewpoint that the covenant was taken pre-phenomenally. He writes, "God extracted the souls (arwāh) [from Ādam] before their bodies (ajsām). He also mentions, a somewhat cryptic notion that "He, be He exalted, extracted simulacra (ashbāh) [of bodies] in which were souls from the back of Ādam, ... and God made them cognisant ('uqūl)...' (Al-Qurțubī 2004, 7:200). Precisely what state the pre-existent souls or bodies existed in, and their respective modes of testifying are unclear. Furthermore, it is not known whether it was a testimony through speech, or through their very being before God. However, it is clear that created beings possessed a knowledge of God and themselves, in the earliest moments of the creation story.

The timing of the first covenant is also disputed, with opinions existing on both sides claiming that the covenant took place either before, or after, earthly existence. Ismā îl ibn 'Abd al-Rahmmān al-Suddī (d. 127/745?) believes that it occurred on the lowest heaven (al-sama $\bar{a}$ al-duny $\bar{a})$, which would indicate it was before earthly existence, but, significantly, still after the fall. Al-Ḥasan al-Bașrī (d. 110/728) believes that after the progeny of Ādam was extracted from his back and the covenant was taken, it was returned to him (Al-Qurțubī 2004, 7:201). Accounting for the different opinions, a potential sequence of events could then be: the creation of Ādam and Hawā'; the fall of man to the lowest heaven; the progeny extracted from Ādam's back; covenant taken; progeny returned to Âdam's back; Ādam lowered to earth. When addressing a conception of the human person, it may be helpful to consider the implications of a pre-earthly existence, and give further thought as to how aspects of the unity and uniqueness of creation contribute to an understanding of the human person. 
Notwithstanding the differences of opinion vis-à-vis when the body and soul came to be united, it is clear that the association of the body and soul, at least in the opinion of many scholars, predates our corporeal existence in the world. We have not yet considered the specific implications of actions on the soul. For this, we must look at the first act of human transgression, and whether it had an effect on the soul.

\section{Fall to Earth: a Case Study of the Interaction between the Body and nafs}

One of the most significant events in the creation story is the Fall of Ādam and Hawä' from heaven to earth, after they consumed fruit from the forbidden tree. The most detailed account of this oft-mentioned narrative in the Qurān is found in The Heights (al-A'rä $f$ ):

"O Ādam, dwell, you and your wife, in Paradise and eat from wherever you will but do not approach this tree, lest you be among the wrongdoers." But Satan whispered to them to make apparent to them that which was concealed from them of their private parts. He said, "Your Lord did not forbid you this tree except that you become angels or become of the immortal." And he swore [by God] to them, "Indeed, I am to you from among the sincere advisors."

So, he made them fall, through deception. And when they tasted of the tree, their private parts became apparent to them, and they began to fasten together over themselves from the leaves of Paradise. And their Lord called to them, "Did I not forbid you from that tree and tell you that Satan is to you a clear enemy?"

They said, "Our Lord, we have wronged ourselves, and if You do not forgive us and have mercy upon us, we will surely be among the losers." God said, "Descend, being to one another enemies. And for you on the earth is a place of settlement and enjoyment for a time. Therein you will live, and therein you will die, and from it you will be brought forth" (Q. 7:19-25).

In this account, it is unclear precisely what form characterized the existence of Ādam and Hawā' in paradise: was it as corporeal or incorporeal beings? Or perhaps it was an existence in between or neither. Further, what role did the form, whether it existed corporeally or ethereally, play in the decision to consume the fruit and what effects manifested in their form as a ramification of that act? Finally, what is one to infer from the notion that their private parts were exposed? Though there is a farrago of opinions on each of these issues, 
what can be concluded is that their physical act had both physical and spiritual consequences for their existence, which caused them to repent and be descended to the earth.

Al-Tabarī, in his exegesis, mentions that there was "a light over their private parts" that dissipated when they ate the forbidden fruit (Al-Tabarī 2005, 5:449). Al-Tha âlibì comments that a number of exegetes view the manifestation of Ādam and Ḥawā's private parts (saw'a) as denoting folly; thus ingestion of the forbidden effected an alteration in their consciousness and awareness of self. He writes, 'this phrase means only that there are imperfections (ma'a $a i b)$ and what diminished their state was exposed to them, it does not denote "private parts"' (Al-Tha ālibì,1996, 1:534). Al-Rāzì is even more explicit that the manifestation of saw'a could connote deterioration in their spiritual state. He writes, 'the manifestation of their saw'a is a metonym (kināya) for their loss of sanctity (hurma) and dissipation of dignity (jāh)' (Al-Rāzī 2004, 14:39).

Al-Qurtubi declares that there was an actual alteration, though not in the physical constitution of Ādam and Hawā', but in the light surrounding their private parts, which still reflected a visible change in them. He writes, "their private parts only became manifest unto both of them, not to anyone besides them, as there was [theretofore] a light (nür) over them, such that their private parts could not be seen, so the light disappeared [when they ate the forbidden fruit]" (Al-Qurțubī 2004, 7:115).

It is evident from this, and other accounts, that the physical act chosen by Ādam and Hawā', effected a change to their consciousness and psyche, and contributed to how they perceived themselves and their bodies. This creates a psychological and physical link between the body and nafs, and raises the question of how physical acts may impact our psychological and physical states, as well as the physical environment around us. The actions of Ādam and Hawā' with their physical, psychological and spiritual consequences, demonstrate that inasmuch as human beings act and produce actions, they and their physical and spiritual fate are also impacted by their actions. In the context of the Islamic tradition, one could go further; in questioning what effect this early event in creation may have had on the collective psyche of humans, and whether this could affect individual notions pertaining to conceptions of the human person. The human genome project which opens up the potential for new knowledge and actions, should consider how it is that this knowledge and subsequent actions could indeed shape what it means to be a human person in its multifaceted dimensions.

Returning to the Fall, whether or not there was a physical change in Ādam and Hawā' following their act of transgression, most scholars agree that there was a metamorphosis in perception and cognizance. This would suggest an 
intimate relationship between nafs and the intellect ('aql). Indeed, Ibn Sīnā believes the two to be so inextricably intertwined that he predicates happiness of the nafs upon achieving intellectual perfection. It thus behooves us to investigate this link further.

\section{Nafs and 'aql}

The ability to reason and engage in rational thought is common to several conceptions of the human person. In the Islamic tradition, the intellect ('aql), and the act of reasoning, located in the soul, is a central step in the journey of human beings fulfilling their purpose for creation. The capacity to reason is called upon in order to establish and strengthen faith ( $\bar{m} m \bar{a} n)$, and for the performance of virtuous actions. Linguistically, " $a q l$, is derived from the expression for the strapping of a camel in order to prevent it from running away...the intellect is thus imagined as a cause for man being restrained from practicing that which is not ethically beautiful" ${ }^{3}$ ('Ajamī 1985).

The Qur'an repeatedly calls humans to think, reflect and reason, using the root word ' $a-q-L$ Not restricting itself to this term alone, it also employs a number of other terms, such as fahm (understanding) (Q. 21:79), nuha (intelligence) (Q. 20:54), hijr (intelligence) (Q. 89:5), 'ilm (knowledge), tafakkur (reflection) (Q. 13:3), tadabbur (contemplation) (Q. 38:29), lubb (inner heart) (Q. 3:190) and hikma (wisdom) (Q. 2:269). The strenuous emphasis on reason in the Qur'an may have inspired the preoccupation of Muslim scholars and philosophers to speculate about the intellect, as evidenced by their numerous epistles ${ }^{4}$ on its definitions, loci, nature and functions, as well as ontologically placing the intellect within their respective cosmic schemes of the universe (Davidson 1992).

Islamic philosophers assiduously studied the Greek tradition wherein one of the most widely discussed topics was the development of the theoretical intellect (nous) in man, as elaborated by Aristotle and his commentators. This resulted in a more prominent focus on knowledge of the soul (as a synonym of the intellect), such as we find in Aristotle's De Anima. Some philosophers distinguished between the intellect and the soul, with the former being envisaged

3 Ibn Taymiyya (d. 728/1328) cites Abū l-Barakāt al-Baghdādī (d. 56o/1164?) in his book al-mútabar fi'-hikmah who mentions: “In Arabic, 'aql means the thing which controls man's whims and desires... This thinking element which controls whims is called 'aql because it prevents man from carrying out his intentions in the same way that the rope called 'uqāl binds the camel, preventing it from moving to any place it wants.' (Salim 1979)

4 Examples of such works include Abu Nasr Fārābỉs (d. 339/950), Risālat fìl-'aql and Miskawayh's (d. 421/1030) Min kitāb al-'aql wa al-Ma'qūl. 
as a spiritual and incorporeal substance, while the latter being conceived of as something linked to the body as a potential intellect.

For Avicenna, the rational soul has two components, namely, a practical intellect and a theoretical intellect. The practical intellect is the lower, downward facing, active component of the soul that is responsible for movement, controls bodily appetites and governs all other faculties of the body. Through the act of deliberation, and the help of the theoretical intellect, it forms the ordinary and commonly accepted opinions, concerning actions and other premises. Good ethical behavior is a result of a successfully functioning practical intellect.

The theoretical intellect, on the other hand, is on a higher plane, and this is the soul's upward facing component, it is passive and receives information, through contemplation from the celestial intelligences. This is the faculty responsible for the pure cognition of truth, receiving and acquiring intelligibles, and impressions (imprinted on the mind) of universal forms (ideas) abstracted from matter, through a connection with the Active Intellect ('aqlfa'cäl).

The Active Intellect is an intelligence that is always in actuality; it bestows intelligible forms on the potential intellect. In Avicenna's cosmological model, the Active Intellect arises from the emanation scheme, in a top-down hierarchical structure for the flow of existence and thought in the universe, starting with God. Avicenna includes three stages of potentiality before the intellect becomes an actual intellect. "The first is the material intellect ('aql hayulānī) which is a potentiality for thinking, the second which is possible potentiality ('aql bil malaka), and possesses principles of knowledge; while the third is the perfection of this potentiality, the actual intellect ('aql bi'l-fic)' (Rahman 1952, $89)$.

Thus, despite the crucial role of the body, human intellection is not purely a bodily function, nor is it entirely individual. Islamic schemes of intelligence rely on the soul, and a cosmic intelligence, "which broadcasts an undifferentiated range of forms," in the wider cosmological schemes of the universe. Islamic conceptions of the human person may be enriched by accounting for the individual's ability, in accordance with its soul-body amalgam, of being able to reason and acquire knowledge. This knowledge, in the Islamic tradition, includes knowledge of the self and God, for "He who knows himself, knows God."

The acquisition of knowledge, nevertheless, is not the only conduit to knowing oneself and one's Lord. Indeed, inspired by the Qurān, Abū Hāmid al-Ghazālī (d. 505/1111) clearly advocates a path to God through repristination of the heart, and the soul. In so doing, he forges a connection between the two most significant terms, from a Qurānic perspective, that are here considered: nafs and qalb. Tying the diverse threads of intellect, nafs, and heart (qalb) to- 
gether, and considering these in light of the human genome project - which has the capacity to affect and influence some, if not all, of these loci of intellection - remains a challenge that has to date, not only not been met, but also has not been considered.

\section{Nafs and qalb}

The Qurān predicates the human being's successful return to God upon a sound heart (qalb salim) (Q. 26:89; 37:84) and a purified soul (nafs zakiyyah) (Q. 91:7-9). As the human person is described in physical and metaphysical terms, so do Quraanic references of the heart that similarly signify both physical and spiritual dimensions. Although Qurānic descriptions of the heart include words loaded with physical connotations such as diseased (Q. 2:10), sealed (Q. 2:7), and hardened (Q. 5:13), the overriding emphasis remains very much on the non-physical heart. Nafs and qalb share traits that are described in the Qurān in similar ways: both have the capacity to "earn" deeds ('nafsin mā kasabat' (Q. 2:281) and 'kasabat qulübukum' (Q. 2:225)) and as a consequence (of earning good ones) have the potential to reach a state that is mutma'in ('annafs al-mutma-innah' (Q. 89:27) and 'tatma-inn al-qulūb' (Q. 13.28)). It can thus, be supposed that nafs and qalb each contribute significantly to the physically manifest metaphysical conceptualization of the human person.

Contrary to Islamic philosophical schema wherein intellect is localized in the nafs, the Qurannic paradigm designates the heart as the locus of reflection (yatadabbaru) (Q. 47:24), reasoning (ya'qilüna) (Q. 22:46), and understanding (yafqahüna) (Q. 7:179). The heart deliberates, makes judgements, and becomes resolute on decisions for which it will be held to account, and in cases deemed sinful (Q. 2:225; 2:283). On several occasions the Qurān makes mention of qalb alongside hearing $\left(\mathrm{sam}^{c}\right.$ ) and sight (bașar) (Q. 2:7; 6:46; 22:46), thus connecting the heart directly with sensory input. It calls human beings to use their hearts to reflect upon information garnered by their senses to arrive at faith. Thus, the heart is made the seat of faith (fi quiübihim al-imān) (Q. 58:22). This interaction of the heart with sensory input offers another consideration for the human genome project, where it ought to take into account the potential impact of the physical on other dimensions of the human person's existence and experience. In the Islamic narrative, the actions of a person influence the level of faith (immann) in the heart, which can increase or decrease. Given that the heart is the locus of faith, the body therefore has the capacity to affect the state of the heart. Qalb, as a nexus between the sensory and spiritual worlds, may thus be the connective tissue that links the body—in its outward facing, physical 
role-- with the nafs - in its inward facing, spiritual one - thereby forging a body-qalb-nafs composite.

In his chef d'oeuvre, Ihyä' ulüm al-dīn, under the chapter of "ajā'ib al-qalb", al-Ghazālì deals with the terms qalb, nafs and rūh, with the focus being on the heart, the actions it inspires and the knowledge to which it may be privy. Purity of the heart, attained through acts of worship and remembrance of God, is a prerequisite for authentic knowledge of God, says the theologian. He draws a connection between the physical heart and the spiritual realms, between the limbs and the heart, and how the heart is influenced by the actions of the limbs (al-Ghazālī 2007, 1:858-86).

The foregoing views of theologians, philosophers and exegetes on the nature of the human person demonstrate that a range of positions was held regarding the physical and metaphysical dimensions that constitute the human person. These include the soul, the spirit, body, intellect, and heart, and their respective functions in human person's journey. Notwithstanding differences in the nature, method and comprehensiveness of these opinions, the essence is that an understanding of the human person cannot be limited to the physical, and that the spiritual and metaphysical dimensions must also be considered. This necessitates that an ethical evaluation of the human genome project should examine how it facilitates or hampers the journey of the human person towards God.

\section{On the Interrelationship of the Soul, Genome and Human Person: a} Primer for Future Research

The above discussions elucidate the inextricable connection of the soul to the human person, and how conceptions of the latter are being further informed by recent developments in genomics. Earlier sections of this paper presented the complex interplay between genes and the human psyche and how genes may confer aspects of our mental capacities. One mechanism of genetic traits determining cognitive states is through the phenotypic determination of our sensory receptors and neural circuitry. Recent neuropsychological studies have investigated the role that external stimuli play on emotions and the subconscious (Winkielman and Berridge 2011). As we rely on our sensory receptors to first collate information from external stimuli and our cortical and subcortical structures to process this data through internal modification, the embryonic formation and subsequent development of these devices all rely on precise genetic coding and programming. Yet, we cannot precisely determine how far this internal modification is carried out through our hard-wired neural circuit- 
ry. Despite this, we may reasonably assert that sensory input, at least to some degree, affects the intellect ('aql) in ways which we are neither aware, nor have taken cognizance of. Since the metaphysical relationship between the ' $a q l$ and nafs and qalb has already been established, we can speculate a link between genes, their role in sensory reception and the subsequent influence on the soul. The soul plays an integral role in the performance of actions, and reciprocally, the actions of a person impact the soul. These attributes of the soul interconnect and overlap with the aforementioned descriptions of genetic traits and their probable correlation with physical attributes that confer the ability to perform actions. In the context of a discussion relating to faith, this relationship allows us to tentatively consider how it is that a potential alteration of the human genome may impact the soul - not in its constitution, but in its propensity for particular types of actions. Given that the actions of a person are considered to have an impact on the soul (nafs) and heart (qalb), we may cautiously posit that genomic alterations of the body, which can impact a person's actions, could in turn have metaphysical and spiritual consequences, by impacting the non-physical dimensions of a human person.

This paradigm can be further elaborated in terms of health, illness and suffering. Illness and disease in Islam are suffering incurred by believers that may act as a means of spiritual cleansing where religious transgressions are manifest as ailments, or as a means of elevating the devotee (Al-Shahri 2005, 432-6). Patiently endured, such suffering is considered a means of expiation of sins and thus a vehicle for increasing one's level of faith. Although the Islamic tradition urges the prevention of disease and the seeking of cures, if genetic alteration leads to a sterile or disease-free human genome then the question can be raised of how such advancements would impact existing understandings of suffering, spiritual cleansing and subsequent faith. Despite such possibilities, the role and interaction of genes with the environment in determining suffering remain. It may be argued that although genes can undergo "disease-free" modification, there are myriad environmental risks that leave man's fate prone to disease.

Furthermore, could a change in the capacity of persons, conferred through genomic alteration of organs and limbs, influence their accountability? Given that "God does not charge a soul except [with that within] its capacity" (Q. 2:286) how would manifestations of these altered capacities impact the soul? Additional to disease and therapy, how would concerns related to enhancement map onto Islamic understandings of human capacity and accountability? Elaboration of such questions, through future research, may further elucidate the interrelatedness of the genome, soul and human person that this paper seeks to initiate. 


\section{Conclusion}

This paper explores the connection between the physical and non-physical dimensions of the human person to broaden the scope of ethical discussions concerning the human genome project. A multifaceted conception of the human person in the Islamic tradition is informed by differing beliefs about the body, soul and spirit - their origin and existence, nature of interaction, and purpose for creation. Through surveying key terms, and subsequent theories on the nature and interaction of the non-physical aspects of a human person with the body, the centrality of the soul for a person's experience and existence is established. The non-physical dimension of a human person, identified here as nafs, influences the body, and the body, as the physical dimension of a human person influences the nafs. A more detailed exploration is required to determine the extent to which the body influences the non-physical dimension of human existence, and the role of nafs in inclining towards or away from good actions. Yet, this narrative opens up a pathway to question the metaphysical repercussions of physical changes in the body through the human genome project, which may facilitate the perpetuation of good or bad deeds.

In the Islamic narrative, the purpose of human existence is associated with a higher spiritual journey and a return to ftrah; thus any project impacting this existence ought to consider the nature and extent to which the soul's propensity for returning to its primordial state of purity and obedience may be affected. The human person's striving in this life to reenact the first covenant- the moment at which the realization of faith was at its greatest - is a physical endeavor with spiritual manifestations. This striving is undertaken by the human person through actions carried out by the body, which have a purifying potential and the possibility of increasing a person's faith. Given that the locus of faith is the soul, the body is therefore capable of influencing, through its actions, the state of the soul. It can be reasonably questioned what impact the human genome project could have on a person's ability to recollect the first moment of witnessing and being before God.

Although this paper is constructed on the views of Islamic scholars who inherited the bifurcation of body and spirit from the Hellenistic tradition, the Qurānic conception and categorization of man does not gainsay the possibility, even probability, of spirituality being resident in, and an intrinsic property of the human body. This sacralised conception of the body demands closer scrutiny through the lens of the Qurānic discourse, and may have ethical implications for genomics.

This is a preliminary survey, engaging two fields that have hitherto been presumed to be disparate, if not entirely antipodal. It has forged an interstice 
between them and carved a landscape wherein they cohabit. This paper lays the groundwork for subsequent analyses that can take up the multitudinous strands of relations delineated, and interactions defined here, to arrive at a higher plateau of knowledge about the spiritual dimension of human existence, and our understandings of the human person.

\section{References}

al-Ash'arī, Abū al-Ḥasan 'Alī ibn Ismāîl. 1963. Maqālāt al-Islāmīỳñn wa ikhtilāf almuṣallīn. Edited by Helmut Ritter. Vīsbādin : Dār al-Nashr Frānz Shtāynir.

al-Attas, Syed Mohammad N. 1995. Prolegomena to the Metaphysics of Islam. Kuala Lumpur : International Institute of Islamic Thought and Civilization.

al-Ghazālī, Abū Hamid. 1963. Macāirij al-quds fì madārī márifat al-nafs. al-Maktabah al-Tijārīyah al- Kubrá, Cairo.

al-Ghazālī, Abū Ḥāmid. 2007. Ihyā’ ulūm al-dīn. Cairo: Dār al-Salām. Vol. 1:858-9o8 al-Iṣfahānī, Rāghib Abū al-Qāsim al-Ḥusayn ibn Muhammad. 2001. Kitāb al-dharīāah ilá makārim al- sharīah. Dimashq: Dār Iqra’.

al-Qurțubī, Abū 'Abd Allāh. 2004. Tafsir al-Qurțubī. Beirut: Dār al-Kutub al-ilmiyya, al-Qushayrī, 'Abd al-Karīm. Lațāìif al-Ishārāt. 4: 304. Online version available at Maktabah Shamilah - Islamic Library.

al-Rāzī, Fakhr al-Dīn. 2004. Al-Tafsìr al-kabìr. Beirut: Dār al-kutub al- ilmiyya.

al-Shahri, Mohammad Z., and Abdullah Al-Khenaizan. 2005. "Palliative care for Muslim patients."J Support Oncol 3.6 432-6.

al-Sulamī, Abū 'Abd al-Rahmān. 20o1. Haqā̄iq al-tafsìr. Beirut: Dār al-kutub al-ilmiyyah.

al-Ṭabarī, Muhammad ibn Jarīr. 2005. Jāmic al-bayān fì ta’wül al-Qur'ān. Beirut: Dār al-kutub al-ilmiyyah.

al-Tha'ālibī, 'Abd al-Rahmān. 1996. Al-Jawāhir al-hisān fì Tafsīr al-Qur'ān. Beirut: Dār al-kutub al-ilmiyyah.

Brockopp, Jonathan E. 2008. "Islam and bioethics." Journal of Religious Ethics, 36 (1):312.

Buchanan, Allen, Dan W. Brock, Norman Daniels, and Daniel Wikler. 2001. From Chance to Choice: Genetics and justice. Cambridge University Press.

Calverley, Edwin Elliott, James W. Pollock. 2002. Nature, man and God in medieval Islam : 'Abd Allāh Baydāww's text, Tawali' al-anwar min matali' al-anzar, along with Mahmud Isfahani's commentary, Matali' al-anzar, sharh Tawali'al-anwar. Leiden: Brill V1.

Colledge, W. H., and M. J. Evans. 1995. "Cystic fibrosis gene therapy." British medical bulletin 51, no. 1: 82-9o.

Crick, Francis. 1994. The Astonishing Hypothesis: The Scientific Search for the Soul. Si- 
mon and Schuster, London.

Dar-Nimrod, Ilan, and Steven J. Heine. 2011. "Genetic essentialism: on the deceptive determinism of DNA." Psychological bulletin 137, no. 5: 8oo.

Davidson, Herbert A. 1992. Alfarabi, Avicenna, and Averroes, on intellect: their cosmologies, theories of the active intellect, and theories of human intellect. Oxford University Press

Dawkins, Richard. 2016. The selfish gene. Oxford: Oxford University Press.

Fārābī. 1938. Risālat fíl-'aql. Edited by Maurice Bouyges. Beyrouth : Imprimerie Catholique

Farrell, Peter T. 1969. "The XYY syndrome in criminal law: an introduction." John's $L$. Rev. 44: 217.

Fox, Richard G. 1971. “The XYY offender: a modern myth?” The Journal of Criminal Law, Criminology, and Police Science 62, no. 1: 59-73.

George J. Annas. 1997. Standard of care: the law of American bioethics. Oxford University Press, USA.

Ghaly, Mohammed. 2012. "The beginning of human life: Islamic bioethical perspectives." Zygon 47 (1):175-213.

Goodman, Lenn Evan. 1992. Avicenna. London: Routledge.

Hawwā, Sāīd. 1995. al-Asās fíl-sunnah wa fiqhihā. Vol 1. Online version available at Maktabah Shamilah - Islamic Library.

Ibn Taymīyah, Aḥmad ibn 'Abd al-Ḥalīm, 1979. Dar' ta'āruḍ al-'aql wa-al-naql ed. Muhammad R.S. Jāmi'at al-Imām Muḥammad ibn Su'ūd al-Islāmīyah.

International Human Genome Sequencing Consortium (IHGSC). 2004. "Finishing the euchromatic sequence of the human genome." Nature 431, no. 7011: 931-945.

Izutsu, Toshihiko. 2002. Ethico-religious Concepts in the Qur'ān. Montreal: McGill-Queen's University Press

Lander, Eric S., Lauren M. Linton, Bruce Birren, Chad Nusbaum, Michael C. Zody, Jennifer Baldwin, Keri Devon et al. 2001. "Initial sequencing and analysis of the human genome." Nature 409, no. 6822: 860-921.

Lane, Edward W., and Stanley Lane-Poole. 1984. Arabic-English lexicon. Cambridge: Islamic Texts Society

Mohamed, Yasien. 2006. The Path to Virtue: The Ethical Philosophy of al-Rāghib al-Ișfahānī: An Annotated Translation, with Critical Introduction, of kitāb al-dharīah ilā makārim al-Sharīah. Kuala Lumpur: ISTAC

Noble, Denis. 2008. "Claude Bernard, the first systems biologist, and the future of physiology." Experimental Physiology 93, no. 1: 16-26.

Peters, Ted. 2014. Playing God? Genetic Determinism and Human Freedom. London: Routledge.

Plomin, Robert, and Frank M. Spinath. 2014. "Intelligence: genetics, genes, and genomics." Journal of personality and social psychology 86, no. 1: 112. 
Rahman, Fazlur. 1952. Avicenna's Psychology: an English translation of Kitāb al-Najāt, Book II, Chapter VI with historico- philosophical notes and textual improvements on the Cairo edition. Oxford: Oxford University Press.

Reisman, David, and Jon McGinnis. 2004. Interpreting Avicenna: science and philosophy in medieval Islam : proceedings of the Second Conference of the Avicenna Study Group. Leiden, Boston: Brill.

Rommens, Johanna M., Michael C. Iannuzzi, Bat-sheva Kerem, Mitchell L. Drumm, Georg Melmer, Michhael Dean, Richard Rozmahel et al. 1989. "Identification of the cystic fibrosis gene: chromosome walking and jumping." Science 245, no. 4922: 10591065 .

Savulescu, Julian, Ruud ter Meulen, and Guy Kahane, eds. 2011. Enhancing human capacities. New Jersey: John Wiley \& Sons.

Savulescu, Julian. 2009. "Genetic interventions and the ethics of enhancement of human beings." Read Philosoph of Tech 16, no. 1: 417-430.

Savulescu, Julian. 2009. "Moral Status of Enhanced Beings: What Do We Owe the Gods?" In: Human Enhancement, edited by Savulescu, Julian, and Nick Bostrom, 211250. Oxford University Press on Demand.

Shaw, Alison. 2014. "Rituals of Infant Death: Defining Life and Islamic Personhood." Bioethics 28 (2): 84-95.

Singer, Peter. 1995. Animal liberation. New York: Random House.

Singer, Peter. 2011. Practical ethics. Cambridge: Cambridge University Press.

Steinbock, Bonnie. 1978. "Speciesism and the Idea of Equality." Philosophy 53, no. 204: 247-256.

Taylor, Charles. 1985. Philosophical papers: Volume 1, Human agency and language. Cambridge: Cambridge University Press.

Tobias, Edward S., Michael Connor, and Malcolm Ferguson-Smith. 2011. Essential medical genetics. Vol. 22. New Jersey: John Wiley \& Sons.

Tutu, Desmond. 2015. In The Emergence of Personhood: A Quantum Leap? Edited by Jeeves, Malcolm, ix. Michigan: William B. Eerdmans Publishing.

Warren A. Mary. 2013. "Abortion”. In A companion to ethics. Edited by Peter Singer. New Jersey: John Wiley \& Sons. 303-315.

Watson, J, quoted in Leon Jaroff. 1989. The Gene Hunt, TIME, Mar. 20, at 62, 67.

Watson, James D., and Francis H. C. Crick. 1953. "Molecular structure of deoxypentose nucleic acids." Nature 171, no. 4356: 737-738.

Wildman, Derek E., Monica Uddin, Guozhen Liu, Lawrence I. Grossman, and Morris Goodman. 2003. "Implications of natural selection in shaping 99.4\% nonsynonymous DNA identity between humans and chimpanzees: enlarging genus Homo." Proceedings of the national Academy of Sciences 100, no. 12: 7181-7188.

Wolfson, Harry Austryn. 1976. The philosophy of the Kalam. Cambridge, Massachusetts: Harvard University Press. 
Wolpe, Paul Root. 1997. "If I am only my genes, what am I? Genetic essentialism and a Jewish response." Kennedy Institute of Ethics Journal 7, no. 3: 213-230.

Zwart, Hub. 2009. "Genomics and identity: the bioinformatisation of human life." Medicine, Health Care and Philosophy 12, no. 2: 125-136. 